\title{
IMPROVING STUDENTS' READING COMPREHENSION THROUGH LISTEN-READ-DISCUSS (LRD) STRATEGY AT MA NURUSSABAH PRAYA TENGAH
}

\author{
Terasne $^{1)}$, Nanang Sugianto ${ }^{2)}$, Abdul Wahab ${ }^{3)}$, Maria Ulfa ${ }^{4)}$ \\ FPBS IKIP Mataram \\ terasne83@gmail.com ${ }^{1)}$,nanang_gomong@yahoo.com ${ }^{2}$,wahab12@gmail.com ${ }^{3)}$,ulfam0170@gmail.com ${ }^{4)}$
}

\begin{abstract}
This research was aimed at describe whether listen-read-discuss (LRD) strategy be able to improve students' reading comprehension or not. It was a classroom action research. The data collected uses quantitative and qualitative data. Quantitative data was gained from the result of pre-test and post-test from reading test. Meanwhile, qualitative data was gained from the result of observation sheets toward students and teachers activity. The instrument uses were test and observation sheet. The result shows that the strategy be able to improve the students' reading comprehension in report text. The improvement can be seen from the mean score of students from pre-test, post-test one, and post-test two. The mean score of pre-test was $69.5(35 \%)$, there were seven students who passed the minimum passing grade, in the post-test one, $72.2(60 \%)$, twelve students passed the minimum passing grade and in the post-test two, $78.25(85 \%)$, seventeen students passed the minimum passing grade (KKM).
\end{abstract}

Keywords: Listen-Read-Discuss, Reading Comprehension

\section{INTRODUCTION}

Reading is the process using to get idea from text, reading enables for people to get the information from the varieties of text, such as written or printed information from newspapers, magazines, and brochures. Beside that, reading as one of the language skill has an important role for facilitating students to learn a foreign language, in which through reading the students are expected to be able to find the information from the text, identify the main idea, identify the explicit or implicit from the text and understanding the purpose of the text.

In reading, not only read the text but also the students' must comprehend and understand the meaning of the text. According to Kustaryo (1988) reading comprehension means understand what has been read, and it is an active thinking process that depends not only on comprehension skill but also the students' experience and prior knowledge comprehension involves understanding of vocabulary seeing the relationship among words and concept organizing ideas, recognizing ideas, recognizing author's making judgments and evaluating. So, from this point of few, it can be said that the reading comprehension is very important for the students if the student does not understand what they read they cannot catch the meaning of the text.

Teaching reading in senior high school is conducted based on the instructional objectives in English curriculum. It is states that in reading competence, the students are expected to understand the meaning of interpersonal and transactional written text in the form of recount, narrative, procedure, descriptive, report, analytical exposition, hortatory exposition, and spoof, so that students are not only expected to 
understand the text but also the student can access the knowledge.

In reality, most of the students are interested in reading, but there are some of the students do not like reading, they cannot understand what they read and do not comprehend the material they read. Based on preliminary research done, the researcher found the problems; Some of students are not able to identify main idea, they cannot identify reference of word and conclude the topic and the last is they difficult to find the important point of the text. Those, facts passed by MA Nurussabah Praya Tengah. It means that the students were lack of reading comprehension, on the other hand, the students' reading comprehension does not improve, it based on the information from small project of done by their English teachers.

This is a reason the writer would like to apply a strategy in teaching reading called Listen - Read - Discuss (LRD) strategy. It is strategy could be activating the students, it focuses on knowledge of students to get good comprehension in reading and the researcher would like to choose the research to improve the students reading's comprehension.

According to Kustaryo

reading comprehension means understand what has been read, and it is an active thinking process that depends not only on comprehension skill but also the student experience and prior knowledge comprehension involves understanding of vocabulary seeing the relationship among words and concept organizing ideas, recognizing ideas, recognizing author's making judgment and evaluating. So from this point of few, it can be said that the reading comprehension is very important for the student if the student does not understand what they read they cannot catch the meaning of the text.

Brown (2003) types of reading into four categories:

a. Perspective

Perspective reading task involves attending to the components of larges stretches of discourse: letters, words, punctuation, and other grapheme symbol.

b. Selective

These categories in order ascertain one's reading recognition of lexical, grammatical, or discourse feature of language within a very short stretch of language, certain typical task are used: picture-cued tasks, matching, true/false, multiple choice.

c. Interactive

Interactive reading is process of negotiating meaning, the reader brings to text a set of schemata for understanding it, and take is the product of that interaction.

d. Extensive

Extensive reading applies to text of more than a page, up to and including promotional articles, assays, technical reports, short stories, and books. However, the researcher only focuses on the interactive, because based on the level of senior high school the student has able to comprehend.

Listen - Read - Discuss strategy is a strategy help the students understand a text. The teachers give a short lecture to the students. Then the students read the text that the teacher spoke about story. After reading, the students discuss the 
information they read and the lecture of the teacher gave. This strategy also helps the students use their prior knowledge. Jennifer Hamilton in her article stated that listen, read, discuss strategy is a good strategy to teach reading material, the students to hear the lecture from the teacher first before even reading. In this step, the students use their prior' knowledge about the text then the struggling readers into the discussion because the text is discussed before reading. In addition, Jennifer Hamilton's statement is supported by Tarek Elabsy (2013) stated that for the struggling students, who have difficulty reading proficiency on their own, benefit from this activity because they activate their prior knowledge through listening to the teacher's introduction of the topic. The teacher asks the students to listen to his or her presentation, to read, and to discuss what they read with each other to deepen their understanding. Therefore, to ensure student interest, the teacher should select topics of which students do not have prior knowledge. Another experts also state like that, their opinion is almost same with other, one of them is coming from Alvermann (1987), he stated Listen reading - Discuss strategy is a strategy guides students to be an active student in learning. Here the students can be trained to be better listener, reader, and speaker. The teacher first lectures about a selected portion of material. Students then read that portion with the purpose of comparing the lecture and the written content afterward the students and teacher discuss the lecture and reading.

\section{RESEARCH METHOD}

Research is the systematic process of attempting to find out a solution to a problem (when the solution is not known) using an acceptable methodology, Tomal, (2010). In this research, the researcher will use Classroom Action Research (CAR) with mix methods research that is Qualitative and Quantitative approach". According to Kemmis and Mc Taggart, in Burns (2010: 9) this is a cyclic research which each cycle consist of four steps namely plan, action, observation, and reflection (Kemmis and Mc Taggart, in Burns, 2010: 9 ). The following steps of this research are as follow:

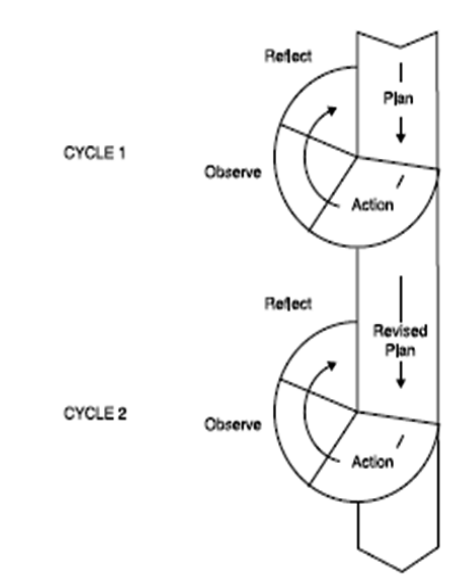

Figure 1. Cyclical AR Model

In each cycle, there are four steps such as planning, acting, observing, and reflecting. If the first cycle is success, the researcher does not need to go to the next cycle. And if the result of the first cycle is unsuccessful, the researcher must be continuing to the second cycle to revise and conduct the steps in the next cycle until achieving the object of the research. So it depends on students score based on the criteria of CAR success. 


\section{Research Subject}

In this research, the researcher chooses MA Nurussabah Praya Tengah as subject of the study especially XI grade students. It consists of 2 classes XI IPS (A class) and XI IPS (B class) and the researcher will take XI IPS (A class) class as subject of the research. It consists of 20 students. The location of MA Nurussabah Praya Tengah, Central Lombok, West Nusa Tenggara.

\section{Instrument of the Study}

The research instrument that used in this study was test and observation sheet. The test was reading test in which the students wrote text in form of report text. The test was conducted in pre-test and post-test. Furthermore, the researcher used observation sheet to observe the teaching and reading process in reading class.

\section{Technique of Data Collection}

To collect the data, the research will give pre-test and post-test to the students. The clear explanation about both of those test are:

1. Pre-test

Before the researcher gives treatment to the students, the researcher will give pre-test to take the data. The researcher will ask for the student to answer the reading test which both of this test have 15 items.

\section{Post-test}

After the researcher teach the students by using LRD, the researcher will give post-test to the students. The post-test contains 15 items of reading test. From the result of post-test, the researcher will take conclusion about this research.

\section{Technique of Data Analysis}

1. Quantitative data

In analyst, the quantitative data, the researcher try to get the average of students' vocabulary score per action in cycle. It will use to know students' performance during learning process of reading comprehension. The researcher will take the data by using reading test. The researcher used objective test. It divides into 15 items of dyadic essay.

2. Qualitative

The qualitative data was the description on the process of listenread-discuss strategy to improve students' reading comprehension in report text from the planning to acting and the observation and also to the reflecting process.

\section{FINDING AND DISCUSSION}

\section{Research Finding}

Cycle I

From the result of students' reading score on cycle 1 after the implementation of Listen - Red - Discuss strategy. It was found that the students who got the highest score $85(5 \%)$ of 20 students was the student initial DI, $80(5 \%)$ there was one student. $77(5 \%)$ one student. $75(45 \%)$ there were nine students. $66(10 \%)$ two student. $65(15 \%)$ there were three students. And the lowest score of 20 students was $60(5 \%)$ was gotten by student initial LAI. The sum of the score was 1.444 . They called pass if their score was equal or more than KKM 75, but they called fail if their score under the KKM 75. Meanwhile, from the twenty students, there were twelve students who pass the minimum passing grade or KKM 75 . 
Based on the calculation, the mean score of reading test in cycle one was 72,2. The highest score was 85 and the lowest score was 60 . The result of the test shown that the comprehension of students was still needed to be improved. Because the students' mean score did not achieve the criteria of success yet 75 . Also, the percentage of students learning achievement were still less, there were only 12 students or $60 \%$ out of the 20 students who achieved the score of KKM while the rest of them were 8 students or $40 \%$ failed. It still needed at least $85 \%$ to reach the standard.

\section{Result of Observation sheet in cycle 1}

The research also observed the student activities jotted down the result into the observation sheet. The result of the observation were as follow:

1) 6 students were focus on their strengths while they managing their weakness (30\%)

2) 5 student were enjoy challenging themselves and setting goals $(25 \%)$

3) 9 students are still deficient in determining a story's core using listen read - discuss strategy (45\%)

The reflection of Classroom Action Research was conducted after getting the result of reading test. Based on the analysis of teaching and learning process and the result of students' reading in first cycle. It showed that the implementation of Listen Read - Discuss strategy not yet gave the satisfactory result in improving students' reading comprehension. The students still got difficulty in reading, the students did not actively in reading process seen from the result of observation checklist. Beside it, the result of students' reading test did not meet yet the criteria of success in which the mean score of post test 1 was 72.2. It was lower than the criteria of success that was 75 . So that's way, the researcher and the collaborator teacher decided to conduct the second cycle.

\section{Cycle II}

Based on the results of student' reading scores in Cycle 2, it could be concluded that the Listen - Read - Discuss strategy could improve the students' reading comprehension. This can be seen from the criteria of success defined in this study. First, the students became more active in the teaching and learning process as seen on the observation checklists. Second, the mean score of the students' reading obtained in post test 2 was 78.25. It was greater than the mean score in post test 1 was 72.2. Therefore, the action research was success.

Based on the result of observation sheet showed the fact during implementation in cycle two those are; First, most of students paid attention to the teacher's explanation because the teacher used both English and Indonesian language to ask them to learn and do the tasks within group to describe particular topic given by investigated it directly to gather some information. They looked very enthusiastic and cooperative. Second, the students more active involved in the groups with the new form of the groups and with the new topic discussed. Third, the students were able to produce acceptable paragraphs because there were found fewer errors than in the first cycle. It because of the teacher gave more control and guidance during the process of making paragraphs until the last process of reading. 


\section{Result of Observation Sheet in Cycle 2}

The researcher also observed the student activities and jotted down the result into the observation sheet. The result of the observation were as follows:

1) 9 students were focused on their strengths while they managing their weakness $(45 \%)$

2) 8 students were enjoy themselves and setting goals $(40 \%)$

3) students were not afraid to acknowledge when they do not something (15\%)

\section{Discussion}

Based on the findings of research, the Listen - Red - Discuss strategy could enhance students' reading ability in descriptive text. It was proven by students' mean score and the total percentage and the students learning activity that increased in every meeting during teaching and learning process. In conducting the teaching and learning process on the first cycle, the researcher found that several of students still seemed confused and difficult to read or find out the ideas and less pay attention to teacher's explanation. Moreover, the result of the students' mean score on the first cycle did not meet the criteria of success. Therefore, the researcher and the collaborator decided together to conduct the second cycle.

Then on cycle two, the activities in this cycle was done better than the cycle one. The students involved actively in learning process and paid attention to the teacher's explanation. They looked enthusiastic to do the tasks by using this strategy and they followed every instruction from their teacher. Through Listen - Read - Discuss strategy involved students work within a group and do the investigation directly toward the object that given by the teacher.

Based on the result of data analysis on cycle 1, it was found the students' highest score was 85 and the lowest score was 60 . Generally, in the cycle 1 , there were 7 students who passed the test beyond the criteria of success was 75 based on the school agreement. And the rest of them 13 students were failed on the test or still under the criteria of success. Meanwhile, on the cycle 2, the students' highest score was 90 and the lowest score was 65 . In this case, the students' progress showed that the students who achieved the criteria of success increased from 12 students $(60 \%)$ on cycle 1 to 17 students $(85 \%)$ in cycle two. From the result of cycle 1 and the cycle 2, it was showed that the Listen - Red - Discuss strategy could enhance students' reading comprehension in descriptive text.

In addition, related to the relevant study in this research, there were some differences and the similarities found those are; based on the research conducted by Nurtalina (2013). It has the same strategy to use in improving students reading comprehension through listen - red discuss strategy. But this research had difference in the use of research design, this research was used the classroom action research, while Nutralina's research used experimental research with experimental group and control group. The result of both these research showed that the use of Listen - Read - Discuss strategy improving the reading comprehension of the students.

\section{CONCLUSION AND SUGGESTION}

After analyzing the data, the researcher could conclude that the 
implementation of Listen - Read - Discuss strategy was able to enhance students' reading comprehension in report text at the tenth grade of MA Nurussabah Praya Tengah. The students' achievement in reading report text was better after implementing the Listen - Read - Discuss strategy. It was proven by the result of the mean score at cycle 1 was $72.2(60 \%)$ and cycle 2 was $78.25(85 \%)$. There was a progress, but the result of cycle 1 was not met the criteria of success yet. Then, the result of observation sheets on cycle one showed that not all of the students involved actively in teaching and learning process.

On cycle 2 was found that there were 17 students or $85 \%$ of 20 students who passed the criteria of success or KKM was 75. In conclusion, by using Listen - Read Discuss strategy was able to enhance students' reading ability in report text, through this strategy was gave chance for students to work together within a group and do the investigation directly toward the object that given by the teacher. And this strategy was called successful based on the findings of the research.

Based on the research finding, Listen - Read - Discuss strategy was able to increase students' reading in report text.This strategy could be the alternative to overcome the students' problem in learning reading. So, the researcher would like to contribute some suggestions for reader, especially:

1. For the Teacher

Listen - Read - Discuss would be helpful to increase students' reading, so the teacher needs to maintain using Listen Read - Discuss strategy in the next new academic year.

\section{For School}

The principle of MA Nurussabah praya Tengah must be considered this strategy to be applied by other teacher with other subject not only English teacher because this strategy is dealing with observation directly to the object.

\section{REFERENCES}

Brown, H. D. (2003). Language Assessment Principles and Classroom Practices. California: Longman Group Ltd.

Introduction $\cdot$ (2003). Handout of
Comprehension. Unpublished. IKIP.
Mataram.

Burns, Anne. (2010). Doing Action Research in English Language Teaching; A Guide for Practitioners. Routledge. New York.

Casale and Manzo. (1985). Literacy and Learning: Reading in the Content Areas. Florida: Ted Buchhoz.

$$
\text { (1985). Listen Read }
$$

Discuss: A Content Reading Heuristic. Journal of Reading.

Charles, Alderson, J. (2000). Assessing Reading. Cambridge University Press.

English Language Institute. (1994). English With Listen Read Discuss Book 1 Beginners. Europe.

Kustaryo. 1988. Action research for teacher candidates. The United States of America.

Manzo, Casale. 1985. The procedure of Listen Red Discuss LRD. Bantam. USA.

TarekElabsy. 2013. Definition of Listen Red Discus edition. PCP. London. 
Wilkinson, David 2009. Using research instruments a guide for researchers. ISBN Details. 